\title{
ANALISIS PENGARUH PENGINDERAAN PASAR, PEMASARAN KEWIRAUSAHAAN, KEMAMPUAN JARINGAN, DAN KEUNGGULAN BERSAING TERHADAP KINERJA PEMASARAN (Studi Pada UKM Makanan dan Minuman di Kota Semarang)
}

\author{
Choirunnisa $^{1}$, Augusty Tae Ferdinand ${ }^{2}$, Farida Indriani ${ }^{3}$ \\ ${ }^{1}$ Magister Manajemen, Fakultas Ekonomika dan Bisnis, Universitas Diponegoro \\ ${ }_{2}^{2}$ Magister Manajemen, Fakultas Ekonomika dan Bisnis, Universitas Diponegoro \\ ${ }_{3}^{3}$ Magister Manajemen, Fakultas Ekonomika dan Bisnis, Universitas Diponegoro
}

\begin{abstract}
ABSTRAK
Penelitian ini bertujuan untuk menguji apakah pengaruh penginderaan pasar, pemasaran kewirausahaan, kemampuan jaringan, dan keunggulan bersaing mempunyai pengaruh terhadap kinerja pemasaran pada UKM makanan dan minuman di Kota Semarang. Penelitian ini mengambil sampel sebanyak 200 responden UKM makanan dan minuman di Kota Semarang. Teknik pengambilan sampel yang digunakan yaitu probability sampling dengan metode simple random sampling. Alat analisis yang digunakan yaitu structural equation model (SEM) pada program AMOS. Hasil analisis data untuk model secara keseluruhan telah memenuhi kriteria Goodness Of Fit yaitu nilai chi-square = 213,800; probability =0,059; CMIN/DF = 1,168; GFI = 0,901; $A G F I=0,875 ; T L I=0,988 ; C F I=0,989 ; R M S E A=0,029$. Dengan demikian, dapat dikatakan bahwa model penelitian yang diajukan dapat diterima. Penelitian ini mempunyai lima hipotesis dan sudah diuji, ada satu hipotesis yang ditolak dan empat diterima. H1 penginderaan pasar memiliki pengaruh positif dan signifikan terhadap keunggulan bersaing. Kemudian, H2 pemasaran kewirausahaan memiliki pengaruh positif dan signifikan terhadap kemampuan jaringan, lalu H3 keunggulan bersaing memiliki pengaruh positif dan signifikan terhadap kinerja pemasaran. Selanjutnya H4 kemampuan jaringan memiliki pengaruh positif dan signifikan terhadap keunggulan bersaing, dan H5 kemampuan jaringan memiliki pengaruh positif dan tidak signifikan terhadap kinerja pemasaran.
\end{abstract}

Kata Kunci: Penginderaan Pasar, Pemasaran Kewirausahaan, Keunggulan Bersaing, Kemampuan Jaringan, dan Kinerja Pemasaran.

\section{PENDAHULUAN}

Usaha kecil dan menengah (UKM) yakni suatu industri yang dapat meningkatkan perekonomian di Indonesia. Pertumbuhan UKM di Indonesia yang semakin bertambah jumlahnya dan belum sejajar dengan kenaikan kualitas UKM yang memadai. Masih melimpahnya persoalan yang dihadapi oleh UKM sehingga menyebabkan kapabilitas UKM untuk bergerak dalam

${ }^{1}$ Corresponding author, Email: nisaachoiir2@gmail.com 
perekonomian nasional tidak dapat maksimal. Saat ini pengembangan UKM sangat penting, dan saat ini UKM juga mendapatkan perhatian penuh dari masyarakat maupun pemerintah untuk bisa bersaing secara kompetitif dengan pelaku bisnis lainnya (Arfanly and Syamsun (2017).

UKM juga telah terbukti mampu bertahan disaat krisis ekonomi terjadi. Kemampuannya dalam bertahan disaat banyak usaha besar yang mengalami kebangkrutan, menjadikan UKM sebagai tulang punggung perekonomian yang mampu menopang kesejahteraan masyarakat. Dengan Jumlah unit usaha yang banyak dan kemampuannya dalam menyerap tenaga kerja memperlihatkan peran strategik UKM dalam pengentasan kemiskinan dan pendorong kesejahteraan masyarakat (Sudaryantoet.al., 2013). Masalah yang dihadapi adalah rendahnya produktivitas yang menimbulkan ketimpangan antara UKM dan perusahaan besar. Menurut Adining (2002) rendahnya produktivitas ini berkaitan dengan: (1) kurangnya karakter sumberdaya manusia dalam hal teknologi, manajemen, organisasi, dan pemasaran; (2) rendahnya rata-rata kemampuan kewirausahaan; (3) sedikitnya daya tampung UKM dalam mengakses teknologi informasi, pasar, permodalan dan faktor produksi lainnya.

Dari banyaknya jenis UKM yang ada di Indonesia, penelitian ini berfokus pada UKM makanan dan minuman yang ada di Kota Semarang Jawa Tengah. Berdasarkan sensus ekonomi yang dilakukan BPS (Badan Pusat Statistik) data UKM yang ada di Jawa Tengah pada tahun 2016 dibagi menjadi 2 kategori yaitu jumlah UKM dari berbagai sektor sebesar 4.174.210 dan total penyerapan tenaga kerja sebesar 9.404 .826 orang dari seluruh UKM yang ada di Jawa Tengah. Sedangkan untuk jumlah UKM makanan dan minuman yang ada di Kota Semarang disajikan pada tabel 1.

\section{Tabel 1}

Jumlah UKM Makanan dan Minuman Di Kota Semarang

\begin{tabular}{l|l|l|l}
\hline Tahun & $\mathbf{2 0 1 6}$ & $\mathbf{2 0 1 7}$ & Total \\
\hline Jumlah & 577 & 2175 & 1488 \\
\hline
\end{tabular}

Sumber: Dinas Koperasi UKM Kota Semarang

Suatu perusahaan secara umum dibangun guna mendapatkan tujuan tertentu dengan menyertakan banyak orang. Untuk mendapatkan keuntungan yang memuaskan dan berkelanjutan agar bisa survive serta memberikan keuntungan baik buat pemilik maupun karyawannya, maka perusahaan dituntut dapat bersaing mengalahkan kompetitornya serta mempertahankan keunggulan yang sudah dimiliki. Manajemen perusahaan dituntut untuk menciptakan kinerja pemasaran yang baik guna mencapai keunggulan tersebut. Lumkin dan Dess (2005) menyatakan bahwa sebuah keunggulan kompetitif ada ketika pelanggan merasakan bahwa produk yang dimiliki perusahaan memiliki kelebihan dari pesaingnya. Selain itu, WillDurant (2010) juga mengemukakan bahwa perusahaan dikatakan mencapai keunggulan kompetitif jika penghematan biaya yang dilakukan oleh perusahaan lebih besar dibandingkan dengan pesaingnya. Selain itu UKM yang berusaha untuk terus meningkatkan kinerja perusahaannya tidak hanya fokus pada keunggulan bersaing saja tetapi juga harus melihat atau memperhatikan faktor lain juga yang dapat meningkatkan kinerja pemasaran yakni pemasaran kewirausahaan, penginderaan pasar, dan kemampuan jejaring.

Pemasaran kewirausahaan yaitu konsep yang bermula dari para pelaku usaha kecil atau para pelaku usaha baru (Stokes 2000). Menurut Morris, et al. (2002) definisi pemasaran kewirausahaan yang paling sering digunakan yaitu 
identifikasi dan eksploitasi proaktif terhadap peluang guna mendapatkan serta mempertahankan konsumen yang memberikan keuntungan melalui pendekatan inovatif terhadap manajemen resiko, pengembangan sumber daya dan penciptaan nilai. Dengan menggunakan pendekatan pemasaran kewirausahaan para pelaku atau para pemilik UKM dapat menghadapi tantangan-tantangan dalam dunia UKM (Kraus, et al. 2009).

Perusahaan yang ingin sukses dalam pasar juga harus mampu melihat peluang pasar atau melakukan penginderaan pasar. Kemampuan penginderaan pasar adalah kapasitas untuk mengumpulkan dan menginterpretasikan pengetahuan dari pasar, termasuk dari pelanggan, pesaing, dan teknologi, dan termasuk kapasitas untuk menyimpan semuanya dalam memori organisasi (Day, 1994; Olavarrieta\&Friedmann,2008) dalam (Lin and Wang 2015). Menurut Lin and Wang (2015) kemampuan penginderaan pasar memungkinkan perusahaan untuk merasakan peluang dan ancaman dari ekosistem bisnis mereka, dan untuk mengambil keputusan dalam menciptakan keunggulan yang masih belum pasti.

Perusahaan yang mempunyai jaringan pemasaran yang luas maka akan memudahkan perusahaan dalam menjual barangnya baik di dalam negeri maupun di luar negeri. Kemampuan jejaring tidak hanya mencari dan mengelola jejaring dengan entitas eksternal (individu atau organisasi) dari perusahaan saja, kemampuan jejaring juga berbicara tentang hubungan jejaring di dalam perusahaan itu sendiri. Seperti yang dijelaskan oleh (Walter, et al. 2006) bahwa empat dimensi kemampuan jejaring adalah koordinasi, keahlian relasi, pengetahuan atas pasar, dan komunikasi internal.
Dalam penelitian ini terdapat dua sumber masalah yakni menyangkut research gap dan fenomena bisnis. Research Gap dalam penelitian ini adalah kontroversi mengenai pengaruh penginderaan pasar dan pemasaran kewirausahaan terhadap kinerja pemasaran. Pada penelitian yang dilakukan oleh Arfanly and Syamsun (2017) mengenai hubungan antara pemasaran kewirausahaan (entrepreneurialmarketing) dan kinerja pemasaran menunjukkan adanya pengaruh langsung dari pemasaran kewirausahaanterhadap kinerja pemasaran, namun demikian studi itu menyisakan pertanyaan besar mengenai proses seperti apakah yang sesungguhnya terjadi sehingga pemasaran kewirausahaan dapat menjadi driver bagi kinerja pemasaran. Sementara menurut Parida, et al. (2016) Untuk meningkatkan kinerja pemasaran dapat melalui inovasi yang berdampak pada kinerja pemasaran, dapat diatasi dengan pendekatan pemasaran kewirausahaan. Konsep orientasi kewirausahaan (EO) berlaku secara universal, dan banyak studi empiris melaporkan sebuah hubungan positif antara EO dan kinerja dalam konteks nasional yang berbeda. Penelitian empiris yang dilakukan Semrau, et al. (2016) melakukan pengujian terhadap orientasi kewirausahaan dengan kinerja pemasaran yang dimoderasioleh Performance Based Culture (PBC) dan Socially Supportive Culture (SSC), hasilnya menunjukkan bahwa PBC secara positif memoderasi hubungan EO dengan kinerja, sedangkan SSC memiliki efek no-moderasi.

Lindblom, et al. (2008) melakukan penelitian mengenai penginderaan pasar perusahaan ritel. Dari hasil penelitiannya memperlihatkan bahwa kemampuan penginderaan pasar berpengaruh secara positif terhadap kinerja bisnis mereka 
(dalam hal pertumbuhan dan profitabilitas), menunjukkan penginderaan menyebabkan tinggi. Morgan.,et.al (2009) yang mendapati kalau variabel Market Sensing Capability tidak mempunyai dampak yang signifikan atas kinerja pemasaran. Pratomo and Widiyanto (2015) mengungkapkan bahwa Market Sensing Capability mempunyai dampak secara signifikan terhadap keunggulan bersaing dan Marketing Performance.

Sedangkan fenomena bisnis dalam penelitian ini yaitu mengenai masalah yang ada di industri UKM makanan dan minuman yang ada di Kota Semarang. Permasalahan pemasaran menjadi pokok utama dalam UKM makanan dan minuman. Dimana para pelaku UKM cenderung banyak yang belum siap menghadapi tingginya persaingan dipasar, belum memiliki merek yang paten, dan lemahnya wawasan dan informasi mengenai pasar. Dilain sisi skala industri rumahan melakukan produksinya terbatas pada pesanan, serta rendahnya jiwa wirausaha juga dapat mempengaruhi cakupan pemasaran produk. Berbagai permasalahan pemasaran ini dapat membuat pendapatan industri UKM lemah dan tidak berkembang. Terlepas dari permasalahan itu, membuat perusahaan kecil untuk beraksi dengan cara berorientasi pasar dan memiliki kontrol dalam pengaturan harga (Tregear, 2003). Oleh sebab itu, agar UKM lebih kompetitif disarankan untuk lebih berorientasi pada pasar (Kara, et al. 2005).

Dari penjabaran diatas studi ini bertujuan untuk mengetahui bagaimana proses penginderaan pasar dapat memberikan dampak yang positif dan signifikan dalam meningkatkan kinerja pemasaran dengan membangun model konseptual. Model konseptual ini akan dikembangkan guna menjelaskan bagaimana proses penginderaan pasar dan pemasaran kewirausahaan dapat meningkatkan kinerja pemasaran UKM makanan dan minuman di Kota Semarang

\section{TELAAH PUSTAKA Orientasi Kewirausahaan}

Konsep orientasi kewirausahaan merupakan suatu konsep studi bisnis dalam bidang manajemen strategis dan kewirausahaan yang sudah ada dalam dunia perbisnisan (Ferdinand and Killa 2014; Madsen 2007; Tang, et al. 2007). Penelitian tentang orientasi kewirausahaan adalah studi yang membahas peran strategis yang dimainkan oleh pengusaha dan bagaimana pengusaha bertindak, bereaksi, proaktif dan memenangkan pasar (Covin and Lumpkin 2011; Lumpkin and Dess 2001). Orientasi kewirausahaan ialah kapabilitas perusahaan untuk melihat peluang usaha baru (Messaghem 2003).

Orientasi kewirausahaan juga dapat dikatakan sebagai alat yang mencakup nilai, atribut, sifat psikologis seseorang, dan sikap yang terkait dengan motivasi untuk berkontribusi dalam kegiatan kewirausahaan(Slamet and Iskandar 2017). Selain itu penelitian yang dilakukan oleh Morris and Paul (2007) menyatakan bahwa orientasi kewirausahaan itu merupakan kecondongan manajemen puncak dalam mengambil risiko, inovatif, dan guna menunjukkan sikap proaktif.

\section{Penginderaan Pasar terhadap Keunggulan Bersaing}

Beberapa peneliti memiliki definisi terkait kemampuan penginderaan pasar yang berbeda-beda antara lain dijelaskan oleh Dias and Lages (2013) bahwa kemampuan penginderaan pasar dianggap sebagai kemampuan yang memungkinkan 
perusahaan untuk memantau kebutuhan dan kecenderungan pasar lebih cepat dari pesaingnya. Sedangkan studi Lin and Wang (2015) menyatakan bahwa kemampuan penginderaan pasar memungkinkan perusahaan untuk merasakan peluang dan ancaman dari bisnis mereka. Studi mengenai penginderaan pasar telah menjadi konsep umum di dalam ilmu pemasaran.

Penginderaan pasar banyak dikembangkan dengan beberapa elemen, pertama mencari dan menggunakan informasi pasar, memprediksi permintaan pelanggan, dan mengantisipasi aksi pesaing, dan mengintegrasikan informasi pasar dan teknologi (Day 2002; Foley and Fahy 2004; Teece 2007), kedua membuat database untuk melayani pelanggan (Lin and Wang (2015). Dimensi-dimensi itu menjadi konsep lintas fungsi menjadi lima dimensi melengkapi dimensi dari dari (Day 2002; Foley and Fahy 2004; Teece 2007).

UKM dengan kemampuan penginderaan akan mampu menunjukkan keterampilan antisipatif dan memprediksi tanggapan pelanggan berubah di depan saingan (Adeniran and Johnston 2012). Ketanggapan mengacu pada kemampuan perusahaan untuk merespon dengan cepat kebutuhan dan keinginan pelanggan (Agha, et al. 2011). Kemampuan penginderaan sebagai salah satu sumber utama keunggulan kompetitif yaitu kemampuan perusahaan untuk belajar tentang pesaing, pelanggan, dan lingkungan bisnis. Akibatnya, perusahaan dengan penginderaan kemampuan menunjukkan keterampilan antisipatif, membuatnya mungkin untuk memahami permintaan pelanggan di depan pesaing (Adeniran and Johnston 2012).

Keunggulan bersaing merupakan salah satu bagian dalam teori RBV (Resource Based Value). Keunggulan bersaing adalah jantung kinerja perusahaan dalam persaingan pasar (Prayhoego 2013). Menurut Adeniran and Johnston (2012) keunggulan kompetitif adalah kemampuan perusahaan untuk menerapkan strategi pasar baru yang memfasilitasi pengurangan harga, produktivitas, dan pemanfaatan peluang pasar yang luas. Meskipun konsep keunggulan kompetitif adalah konsep yang paling sering diambil untuk konsep manajemen strategis (Sigalas 2015), namun keunggulan kompetitif tidak selalu dapat diprediksi, dan kemampuan sumber daya yang mengarah ke proftabilitysuperior dan keunggulan kompetitif yang tidak jelas (Hinterhuber 2013).

Adapun beberapa elemen yang dapat digunakan untuk mengukur keunggulan bersaing antara lain daya tahan lama, tingkat kesulitan untuk dapat ditiru, dan tingkat kemudahan untuk menyamai dalam penelitian (Valeria 2013), harga yang relatif rendah (Ong, et al. 2010), dan pelayanan pelanggan (Bilgihan, et al. 2011). Penginderaan pasar adalah bagian penting dari kesuksesan bisnis. Jika UKM dapat merasakan kondisi lingkungan pasar dengan baik, mereka akan mampu melihat kebutuhan pasar, tren pasar, dan perubahan lingkungan bisnis.

Kemampuan UKM dalam merasakan kondisi pasar akan meningkatkan kinerja perusahaan (Ardyan 2016; Tseng and Lee 2014). Akibatnya, perusahaan yang menggunakan kemampuan penginderaan dapat menunjukkan kemampuan antisipatif untuk dapat memahami kebutuhan pelanggan (Adeniran and Johnston 2012). Pada dasarnya, kemampuan perusahaan untuk menggunakan kecerdasan pasar dan sadar melihat perubahan pasar akan lebih mudah memprediksi pelanggan yang lebih akurat. Dengan kata lain, kemampuan penginderaan dapat memungkinkan UKM untuk bisa mengumpulkan informasi pasar 
dan menginterpretasikan informasi tersebut untuk mendapatkan keunggulan bersaing (Adeniran and Johnston 2012). Oleh karena itu hipotesis yang dapat diajukan adalah;

H1: Semakin tinggi Kemampuan Penginderaan pasar maka semakin tinggi tingkat keunggulan bersaing.

\section{Pemasaran Kewirausahaan terhadap kemampuan jaringan}

Konsep pemasaran kewirausahaan yaitu marger dari konsep entrepreneurship dan marketing(Arfanly, et al. 2016). Beberapa definisi mengenai pemasaran kewirausahaandari para peneliti, antara lain menurut Morris, et al. (2002) definisi pemasaran kewirausahaan yang paling sering digunakan yaitu identifikasi dan eksploitasi proaktif terhadap peluang guna mendapatkan serta mempertahankan konsumen yang memberikan keuntungan melalui pendekatan inovatif terhadap manajemen risiko, pengembangan sumber daya dan penciptaan nilai.Bäckbro and Nyström (2006) pemasaran kewirausahaan adalah aspek yang tumpang tindih antara pemasaran dan kewirausahaan.

Dimensi pemasaran kewirasusahaan menurut Morris (2002) menyatakan ada tujuh dimensi yaitu sikap proaktif, penghitungan dalam pengambilan resiko, kemampuan inovasi, fokus terhadap peluang, pengoptimalan sumberdaya, penciptaan nilai, dan peningkatan intensitas pelanggan. Dimensi itu juga dikemukakan dalam penelitian Morrish\&Deacon (2009) dan penelitian Miles\&Darroch (2006). Kraus, et al. (2009) dalam penelitiannya menunjukkan bahwa pemasaran kewirausahaan (entrepreneurialmarketing) yang telah diterapkan oleh pelaku usaha sudah cukup baik. Dengan adanya kemampuan tersebut, terdapat peluang besar agar usaha yang dijalankan dapat berkembang dan berkelanjutan.

Jika sebuah usaha tidak memiliki wawasan tentang kemampuan jaringan yang harus dilakukan, hal ini dapat mengakibatkan hilangnya kemungkinan perkenalan mitra baru dalam jaringan usaha. Parida, et al. (2017) bahkan menekankan pentingnya untuk aktif mencari rekan jejaring baru karena pertama: nilai hubungan jejaring semakin lama akan berkurang karena fenomena rusaknya jejaring. Kedua: dengan aktif mencari jejaring baru, perusahaan mampu mengeksploitasi peluang yang belum dimanfaatkan. Kemampuan jaringan didefinisikan sebagai kemampuan perusahaan untuk memulai, mengembangkan dan memanfaatkan organisasi internal serta hubungan organisasi eksternal. Jaringan dikembangkan dari hubungan yang kuat mungkin menguntungkan untuk perusahaan (Walter etal., 2006).

Kewirausahaan merupakan salah satu kunci untuk menentukan aktivitas pembangunan kapabilitas perusahaan. Hubungan antara pemasaran kewirausahaan dengan jaringan usaha sebagaimana dalam penelitian Lukiastuti (2013)yang menjelaskan bahwa para pelaku usaha yang mempunyai perilaku inovatif yang tinggi lebih sering untuk mencari nasihat dibandingkan orang yang perilaku inovatifnya lebih rendah. Terdapat bukti empiris yang mengatakan bila wirausaha membaca lebih banyak literatur, maka lebih mungkin bagi mereka untuk bergabung dalam beberapa lembaga profesional serta untuk memperoleh jaringan eksternal peluangnya akan lebih besar. Hal ini membuktikan bahwa orang yang mempunyai orientasi inovasi besar dapat memiliki jaringan eksternal yang kuat. Berdasarkan teori yang telah 
dikemukakan di atas maka hipotesis yang H2: Semakin tinggi pemasaran kewirausahaan, maka semakin tinggi kemampuan jaringan.

\section{Keunggulan Bersaing terhadap Kinerja Pemasaran}

Untuk meningkatkan kinerja pemasaran banyak sekali faktor yang dapat mendukung peningkatan kinerja pemasaran suatu perusahaan salah satunya yaitu melalui keunggulan bersaing. Studi dari Williams (2012) menyarankan bahwa kunci penentu UKM untuk mendapatkan keunggulan kompetitif adalah kemampuan UKM untuk mengembangkan produk yang unik, dan fleksibilitas mereka dalam mengadopsi teknologi baru. Untuk mencapai dan mempertahankan keunggulan kompetitif, UKM dapat berkolaborasi dengan pemasok dan pesaing tertentu untuk membangun jaringan yang kuat. Oleh karena itu, kolaborasi antar organisasi bisa membantu UKM menjadi sangat inovatif, karena memaparkan perusahaan ke teknologi baru dan strategi bisnis baru (Adeniran and Johnston 2012).

Konsep kinerja pemasaran secara luas dibicarakan dalam banyak peneliti ilmiah yang menunjukkan beragam langkahlangkah yang digunakan untuk menunjukkan kinerja perusahaan di bidang pemasaran atau divisi (Ferdinand and Fitriani 2015b). Studi (Farida 2016; Saeko 2012) menyatakan bahwa kinerja pemasaran adalah kunci keberhasilan bisnis sebagai hasil dari strategi pasar untuk pelanggan, pasar, dan organisasi keuangan, kinerja pasar seperti pertumbuhan penjualan, pangsa pasar, dan pengembangan pasar dalam studi kinerja pemasaran.

Rencana yang diterapkan perusahaan selalu berupaya untuk memperoleh kinerja pemasaran dan diajukan pada penelitian ini adalah: keuangan yang baik. Penjualan produk yang meningkat juga otomatis akan meningkatkan volume produk yang terjual yang ditunjukkan oleh nilai penjualan yang juga meningkat (Ferdinand and Fitriani 2015b) dan diharapkan dapat memenuhi atau melampau target keuntungan yang ditetapkan (Mu \& Di Benedetto, 2012). Atas dasar itu maka komponen kinerja pemasaran pada penelitian ini adalah adanya pertumbuhan penjualan (Ferdinand and Fitriani 2015a; Zacca, et al. 2015) yang memenuhi atau melampaui target yang ditetapkan (Mu \& Di Benedetto, 2012), volume penjualan yang meningkat (Ferdinand and Fitriani 2015a), dan nilai penjualan (Ferdinand 2000; Ferdinand and Fitriani 2015a) yang memenuhi atau melampaui target $(\mathrm{Mu} \& \mathrm{Di}$ Benedetto, 2012).

Studi yang dilakukan oleh Meutia (2013) mengatakan bahwa terdapat pengaruh yang signifikan antara keunggulan bersaing terhadap kinerja bisnis. Studi tersebut juga di perkuat dari hasil penelitian (Fauzi and Widiyanto 2015; Mohebi and Farzollahzade 2014) yang menyatakan bahwa keunggulan bersaing memiliki pengaruh signifikan dan positif terhadap kinerja bisnis. Berdasarkan yang sudah dipaparkan diatas, maka hipotesis yang dapat diajukan dalam penelitian ini adalah:

H3: Semakin tinggi keunggulan bersaing maka semakin tinggi kinerja pemasarannya.

\section{Kemampuan Jaringan terhadap Keunggulan Bersaing}

Salah satu aspek penting dalam kinerja pemasaran yaitu keunggulan bersaing, yang menunjukkan bagaimana suatu usaha dapat bersaing dan memiliki keunggulan dibandingkan dengan 
pesaingnya. Keunggulan kompetitif adalah hasil dari nilai yang dibuat oleh perusahaan untuk pelanggan. Pelanggan akan membayar biaya dari nilai atau manfaat ini dan nilai superior yang disebabkan oleh pengaturan harga lebih rendah dari harga pesaing (Mohebi and Farzollahzade 2014). Selain itu aspek psikologi (berdasarkan pengetahuan) mengenai peluang, sumber daya, dan modal dapat memotivasi perusahaan kecil dan pemula untuk terlibat dalam suatu jaringan (Coduras, et al. 2016; Parida, et al. 2017).

Studi Mu (2014) mendefinisikan kemampuan jaringan sebagai kemampuan perusahaan untuk menemukan mitra jaringan dan mengelola hubungan jaringan untuk menciptakan keunggulan kompetitif. Menemukan mitra jaringan pada dasarnya mengacu pada luasnya pencarian yang dilakukan perusahaan untuk mengidentifikasi individu atau organisasi yang tepat dengan mana perusahaan ingin berinteraksi $\mathrm{CM}$ 2014; $\mathrm{Mu}$ and $\mathrm{Di}$ Benedetto 2012). Mengelola hubungan jaringan menunjukkan keterampilan relasional perusahaan dalam menavigasi hubungan jaringan atau hubungan yang efektif dan efisien dengan nara sumber atau organisasi (Mitrega, et al. 2012; Mu 2014; Schilke and Goerzen 2010). Berdasarkan penalaran logis Mitrega, et al. (2012) menyatakan bahwa kemampuan jaringan merupakan faktor penting yang secara signifikan mempengaruhi kinerja perusahaan. Dengan demikian hipotesis yang dapat diajukan yaitu:

H4: Semakin tinggi kemampuan jaringan maka semakin tinggi keunggulan bersaing.

\section{Kemampuan Jaringan terhadap Kinerja Pemasaran}

Membangun hubungan baru itu penting untuk membangun orientasi menjadi inovatif untuk membangun kinerja yang lebih tinggi (Parida, et al. 2017). Kemampuan jejaring tidak hanya mencari dan mengelola jaringan eksternal dari perusahaan saja, kemampuan jejaring juga berbicara tentang hubungan jejaring di dalam perusahaan itu sendiri. Seperti yang dijelaskan oleh $\mathrm{Mu}$ and $\mathrm{Di}$ Benedetto (2012), komponen kemampuan jejaring terdiri dari mencari dan menemukan rekanan, mengelola hubungan dengan rekanan, dan memanfaatkan dengan maksimal hubungan yang ada.

Parida, et al. (2017)mengemukakan lima komponen kemampuan jejaring yang terdiri dari, kemampuan perusahaan mengatur/mengoordinir rekanan-rekanan yang berkolaborasi dengan kita, kemampuan relasi interpersonal perusahaan untuk mempengaruhi rekanan, memiliki informasi atau pengetahuan tentang rekanan perusahaan dan kompetitor, kemampuan komunikasi internal perusahaan dalam menyalurkan pengetahuan yang didapatkan dari rekanan, serta kemampuan perusahaan membangun hubungan baru. Lima komponen kemampuan jejaring dari (Parida, et al. 2017) merupakan pengembangan dari empat komponen yang ditawarkan oleh Walter, et al. (2006) yaitu koordinasi, keahlian relasi, pengetahuan rekanan, dan komunikasi internal.

Perusahaan akan lebih mudah mengenali pasar dan saluran distribusinya melalui jejaring pemasaran yang telah diciptakan oleh perusahaan tersebut. Dengan begitu, perusahaan tersebut dapat dengan mudah memanfaatkan jejaring kerjanya dalam proses pemasaran produk. Dengan semakin luas jejaring yang dimiliki oleh perusahaan maka semakin besar kesempatan perusahaan dalam memasarkan produknya dan meningkatkan ekspornya (Rohmaniyah and Nurhayati 
2017). Studi Fauzi (2015) menjelaskan adanya pengaruh positif dan signifikan antara jaringan pemasaran terhadap kinerja pemasaran. Oleh sebab itu, hipotesis yang diajukan adalah:

H5: Semakin tinggi kemampuan jaringan maka semakin tinggi kinerja pemasarannya.

\section{METODE PENELITIAN Jenis dan Sumber Data}

Penelitian ini menggunakan perhitungan statistik untuk mengolah data-data yang didapatkan dari proses penelitian, sehingga penelitian ini adalah penelitian kuantitatif. Data primer dan sekunder adalah dua jenis data yang dipakai dalam penelitian ini, dengan data primer sebagai sumber data utama yang didukung oleh data-data sekunder lainnya.

\section{Populasi dan Sampel}

Populasi yang digunakan pada penelitian ini adalah semua pelaku usaha UKM makanan minuman di Kota Semarang tahun 2016-2017 sebesar 1488 UKM.Sedangkan sampel yang diambil pada penelitian ini sebesar 200 responden. Teknik pengambilan sampel yang digunakan yaitu probability sampling dengan metode simple random samplingyakni metode pengambilan sampel dimana semua elemen dalam populasi mempunyai peluang yang sama untuk dipilih menjadi sampel (Sugiyono, 2009, p. 81). Dalam penelitian ini anggota sampel dipilih secara acar menggunakan tabel angka random UKM makanan dan minuman di Kota Semarang.

\section{Metode Pengumpulan Data}

Metode yang digunakan adalah dengan memberikan kuesioner atau angket pada responden. Kuesioner disusun secara terrtulis dan memberikan pilihan jawabannya dalam bentuk pernyataan. Untuk memperoleh hasil pernyataan yang akurat maka kuesioner atau angket diukur dengan menggunakan skala interval 1 sampai 10, dengan rentang skala 1untuk pernyataan sangat tidak setuju sedangkan 10 untuk pernyataan sangat setuju. Alasan dibuatnya skala 1-10 adalah pada skala genap bertujuan agar responden yang mengisi tidak cenderung memberi nilai tengah.

\section{Model Penelitian}

Berdasarkan telaah pustaka yang sudah dijelaskan maka model penelitian yang dapat dikembangkan dalam penelitian ini yaitu dapat dilihat gambar 1 .

\section{Gambar 1}

Kerangka Pikir Teoritis

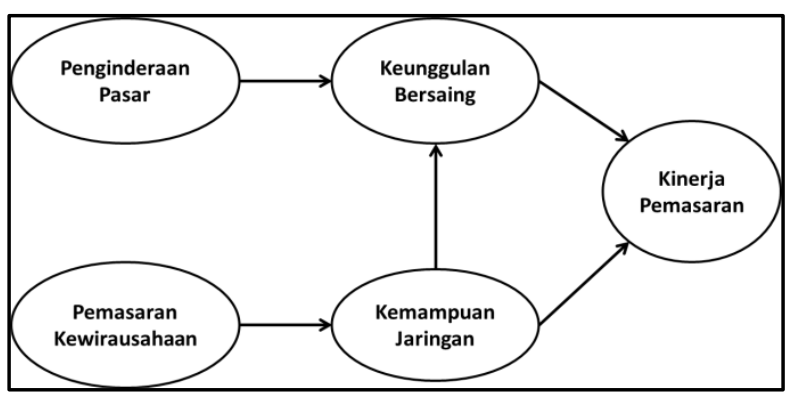

\section{HASIL ANALISIS DATA DAN PEMBAHASAN}

Analisis Kelayakan Model Struktural

Analisis ini berguna untuk menguji full model yang digunakan dalam penelitian setelah model diuji dengan analisis faktor konfirmatori. Hasil pengujian full model ini disajikan pada Gambar 2 dan Tabel 2. 


\section{Gambar 2}

Hasil Uji Model Struktural

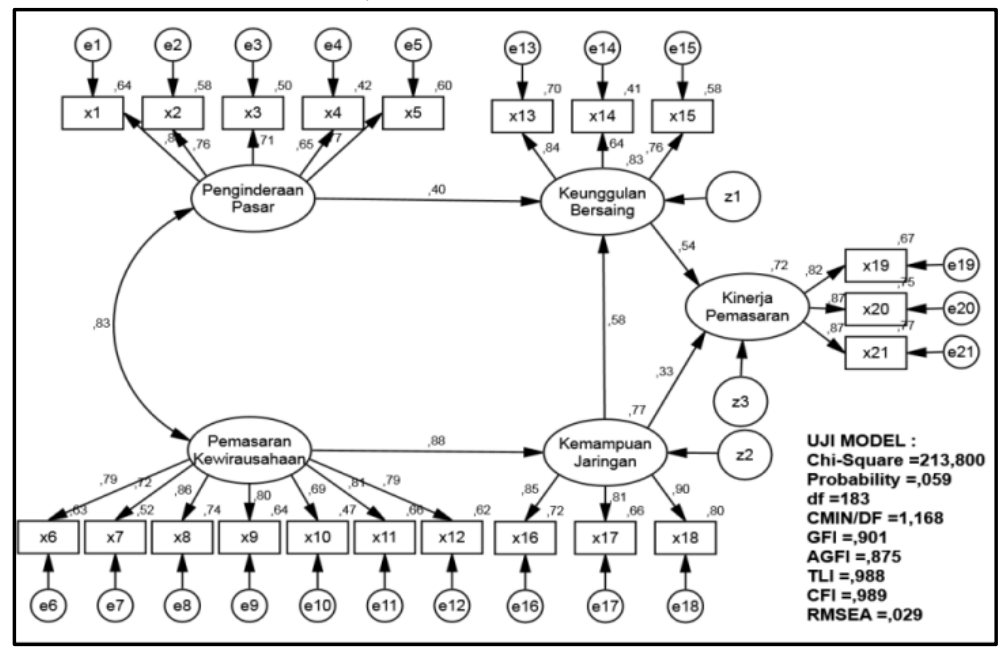

Tabel 2

\section{Hasil Uji Kelayakan Model Struktural}

\begin{tabular}{cccc}
\hline Hasil & Cut of Value & Hasil & Evaluasi \\
Chi Square & Diperkirakan Kecil & 213,800 & Baik \\
Probability & $\geq 0.05$ & 0,059 & Baik \\
AGFI & $\geq 0.90$ & 0,875 & Marginal \\
GFI & $\geq 0.90$ & 0,901 & Baik \\
CFI & $\geq 0.95$ & 0,989 & Baik \\
TLI & $\geq 0.95$ & 0,988 & Baik \\
RMSEA & $\leq 0.08$ & 0,029 & Baik \\
CMIN/DF & $\leq 2.00$ & 1,168 & Baik \\
\hline
\end{tabular}

Hasil pengolahan terhadap keseluruhan model setelah data diolah menggunakan faktor konfirmatori menunjukkan bahwa keseluruhan model dalam penelitian ini telah memenuhi kriteria-kriteria dalam GOF (Goodness Of Fit) yang artinya model penelitian dapat diterima. Untuk menguji hipotesis mengenai kausalitas yang ada dalam model penelitian ini, maka perlu dilakukan uji hipotesis nol $\left(\mathrm{H}_{\mathrm{o}}\right)$ yang menunjukkan koefisien regresi antar hubungan. Hasilnya dapat dilihat pada Tabel 3 dibawah ini:

Tabel 3

Hasil Uji Regression Weights Model Struktural

\begin{tabular}{|c|c|c|c|c|c|c|c|}
\hline & & & Estimate & S.E. & C.R. & $\mathrm{P}$ & Kesimpulan \\
\hline KJar & $<---$ & PKew & 1,092 & ,088 & 12,416 & $* * *$ & Diterima \\
\hline KBer & $<---$ & PPas & ,393 & 100 & 3,943 & *** & Diterima \\
\hline KBer & $<---$ & KJar & ,612 & 107 & 5,732 & $* * *$ & Diterima \\
\hline KPem & $<---$ & KBer & ,429 & 141 & 3,040 & ,002 & Diterima \\
\hline KPem & $<---$ & KJar & ,279 & ,144 & 1,941 & ,052 & Ditolak \\
\hline
\end{tabular}

Tabel diatas menunjukkan tidak semua indikator dari setiap variabel memiliki nila regression weight estimate / loading factor yang signifikan dengan hasil nilai CR 
(CriticalRatio) sebesar $\geq 1,96$ dengan probabilitas $\geq 0.05$. Maka dapat disimpulkan bahwa hipotesis yang ada tidak semuanya diterima.

\section{Pembahasan}

Hipotesis pertama mengindikasi bahwa penginderaan pasar mempunyai pengaruh yang positif dan signifikan terhadap keunggulan bersaing. Hal ini ditunjukkan oleh hasil pengolahan data antara penginderaan pasar terhadap keunggulan bersaing yang menunjukkan hubungan positif dengan nilai C.R(CriticalRatio) sebesar 3,943 dan dengan nilai P-valuesebesar 0,000 (simbol *** artinya sangat signifikan). Data tersebut menunjukkan bahwa penginderaan pasar sebagai salah satu faktor penting dalam meningkatkan keunggulan bersaing. Hasil penelitian ini mendukung penelitian dari Pratomo and Widiyanto (2015); Morgan, et al. (2009); Wachjuni (2017); Fauzi (2015); Adeniran and Johnston (2012); Tseng and Lee (2014); Ardyan (2016). Kemudian, hipotesis kedua mengindikasi bahwa pemasaran kewirausahaan mempunyai pengaruh yang positif dan signifikan terhadap kemampuan jaringan. Hal ini ditunjukkan oleh hasil pengolahan data antara variabel pemasaran kewirausahaan terhadap kemampuan jaringan yang menunjukkan hubungan positif dengan nilai C.R (CriticalRatio) sebesar 12,416 dan nilai P-valuesebesar 0,000 (simbol *** artinya sangat signifikan). Hal ini menunjukkan bahwa pemasaran kewirausahaan berhubungan dengan pencarian jaringan, pengelolaan jaringan, dan komunikasi internal suatu usaha agar dapat berkembang dari pesaingnya. Hasil penelitian ini mendukung penelitian dari Suryanita (2006) dan Lukiastuti (2013).

Hipotesis ketiga mengindikasi bahwa keunggulan bersaing mempunyai pengaruh yang positif dan signifikan terhadap kinerja pemasaran. Hal ini ditunjukkan oleh hasil pengolahan data antara variabel keunggulan bersaing terhadap kinerja pemasaran yang menunjukkan hubungan positif dengan nilai C.R(CriticalRatio) sebesar 3,040 dan nilai P-valuesebesar 0,002. Hal ini menunjukkan bahwa keunggulan bersaing dapat menentukan bagaimana suatu usaha itu dapat bertahan dalam ketatnya persaingan dipasar. Hasil penelitian ini mendukung penelitian dari Meutia (2013); Sinkovics and Roath (2004); Mohebi and Farzollahzade (2014). Selanjutnya, hipotesis empat mengindikasi bahwa kemampuan jaringan mempunyai pengaruh yang positif dan signifikan terhadap keunggulan bersaing. Hal ini ditunjukkan oleh hasil pengolahan data antara variabel kemampuan jaringan terhadap keunggulan bersaing menunjukkan hubungan positif sebesar 0,612 serta nilai C.R(CriticalRatio) sebesar 5,732 dan nilai P-valuesebesar 0,000 (simbol *** artinya sangat signifikan). Hal ini menunjukkan bahwa banyaknya jaringan usaha yang dilakukan para pemilik UKM akan menghasilkan keunggulan yang lebih dibandingkan dengan pesaingnya. Hasil penelitian ini mendukung penelitian dari (Mu 2014); Adeniran and Johnston (2012); Aziz and Samad (2016); Williams (2012).

Hipotesis lima mengindikasi bahwa kemampuan jaringan mempunyai pengaruh yang positif tetapi tidak signifikan terhadap kinerja pemasaran. Hal ini ditunjukkan oleh hasil pengolahan data antara variabel kemampuan jaringan terhadap kinerja pemasaran menunjukkan hubungan positif dengan nilai C.R(CriticalRatio) sebesar 1,941 dan nilai P-valuesebesar 0,052. Hal ini menunjukkan bahwa kemampuan jaringan yang dilakukan belum maksimal sehingga tidak dapat meningkatkan kinerja 
pemasaran secara langsung. Hasil penelitian ini mendukung penelitian dari Parida, et al. (2017); Walter, et al. (2006); Mohebi and Farzollahzade (2014).

\section{Kesimpulan Hipotesis}

Dari hasil pengolahan data dan pembahasan yang sudah dilakukan maka kesimpulan dari penelitian ini yaitu:

(1) Penginderaan pasar terhadap keunggulan bersaing memiliki pengaruh positif dan signifikan sebesar $0,000 * * *$ ).

(2) Pemasaran kewirausahaan terhadap kemampuan jaringan memiliki pengaruh positif dan signifikan 0,000 ***).

(3) Keunggulan bersaing terhadap kinerja pemasaran memiliki pengaruh positif dan signifikan sebesar 0,002.

(4) Kemampuan jaringan terhadap keunggulan bersaing memiliki pengaruh positif dan signifikan sebesar $0,000 * * *)$.

(5) Kemampuan jaringan terhadap kinerja pemasaran memiliki pengaruh positif dan tidak signifikan sebesar 0,052.

\section{Implikasi Manajerial}

Dari penjelasan yang sudah dilakukan maka implikasi manajerial yang dapat diberikan pada penelitian ini adalah:

(1) Para pelaku UKM makanan dan minuman perlu mempertahankan indikator memprediksi permintaan konsumen yang merupakan indikator paling tinggi guna meningkatkan penginderaan pasar. Oleh sebab itu, pelaku UKM harus terus memperhatikan permintaan konsumen untuk mengembangkan usahanya.

(2) Para pelaku UKM makanan dan minuman perlu mempertahankan indikator pengoptimalan sumber daya yang merupakan indikator paling tinggi guna meningkatkan pemasaran kewirausahaan. Oleh sebab itu, para pelaku UKM harus memperhatikan atau mengoptimalkan sumber daya yang digunakan dalam mengembangkan usahanya.

(3) Para pelaku UKM makanan dan minuman perlu mempertahankan indikator menciptakan keunggulan biaya yang relatif rendah yang merupakan indikator paling tinggi guna meningkatkan keunggulan bersaing. Oleh sebab itu, para pelaku UKM harus menciptakan keunggulan biaya yang relatif rendah agar dapat bersaing dengan para pelaku UKM lainnya.

(4) Para pelaku UKM makanan dan minuman perlu mempertahankan indikator pencarian jaringan yang merupakan indikator paling tinggi guna meningkatkan kemampuan jaringan. Oleh sebab itu, para pelaku UKM harus meningkatkan pencarian jaringan untuk memperluas jaringan usahanya diberbagai sektor.

(5) Para pelaku UKM makanan dan minuman perlu mempertahankan indikator volume penjualan yang merupakan indikator paling tinggi guna meningkatkan kinerja pemasaran. Oleh sebab itu, para pelaku UKM harus dapat meningkatkan volume penjualannya agar usaha tersebut mengalami kemajuan dan dapat meningkatkan kinerja pemasarannya.

\section{Agenda Penelitian Mendatang}

Dari poin-poin yang sudah dijelaskan dalam keterbatasan penelitian diatas, maka implikasi yang diajukan hanya terbatas pada variabel yang digunakan dalam penelitian. Penelitian lanjutan diharapkan dapat mengembangkan variabel lain yang dapat mempengaruhi kinerja pemasaran. Pada penelitian ini terdapat 1 hipotesis 
yang ditolak, sehingga perlu adanya riset lebih lanjut dan dalam bentuk model penelitian yang lebih baik.

Maka saran yang dapat diajukan peneliti yaitu apabila dilakukan penelitian yang serupa dengan objek UKM makanan dan minuman di Kota Semarang, maka diharapkan populasi dan data yang diambil yakni seluruh Jawa Tengah agar data yang diperoleh lebih banyak dan penelitian selanjutnya dapat mengembangkan model lain yang berpengaruh terhadap kinerja pemasaran dari faktor-faktor lain.

\section{REFERENSI}

Adeniran, Tejumade V, And Kevin A Johnston. (2012). Investigating The Dynamic Capabilities And Competitive Advantage Of South African Smes. African Journal of Business Management 6(11):4088.

Agha, Sabah, Laith Alrubaiee, And Manar Jamhour. (2011). Effect Of Core Competence On Competitive Advantage And Organizational Performance. International Journal of Business And Management 7(1):192.

Ardyan, Elia. (2016). Market Sensing Capability And Smes Performance: The Mediating Role Of Product Innovativeness Success. DLSU Business \& Economics Review 25(2):1-1.

Arfanly, Bibi, Ma'mun Sarma, And Muhammad Syamsun. (2016). Analisis Strategi Entrepreneurial Marketing Pada Industri Rumahan Kabupaten Kendal Serta Pengaruhnya Terhadap Kinerja Pemasaran, Bogor Agricultural University (IPB).

Arfanly, Bibi, And Muhammad Syamsun. (2017). Peran Entrepreneurial Marketing Dalam Peningkatan Kinerja Pemasaran Pada Industri Rumahan Kabupaten Kendal, Jawa Tengah. Manajemen Ikm: Jurnal Manajemen Pengembangan Industri Kecil Menengah 11(2):141150.

Aziz, Nurul Nadia Abd, And Sarminah Samad. (2016). Innovation And Competitive Advantage: Moderating Effects Of Firm Age In Foods Manufacturing Smes In Malaysia. Procedia Economics And Finance 35:256-266.

Bäckbro, Johan, And Hampus Nyström. (2006). Entrepreneurial Marketing: Innovative Value Creation.

Bilgihan, Anil, Et Al. (2011). Information Technology Applications And Competitive Advantage In Hotel Companies. Journal of Hospitality And Tourism Technology 2(2):139-153.

Coduras, Alicia, José Manuel Saiz-Alvarez, And Jesus Ruiz. (2016). Measuring Readiness For Entrepreneurship: An Information Tool Proposal. Journal Of Innovation \& Knowledge 1(2):99-108.

Covin, Jeffrey G, And G Thomas Lumpkin. (2011). Entrepreneurial Orientation Theory And Research: Reflections On A Needed Construct. Entrepreneurship Theory And Practice 35(5):855-872.

Day, George S. (2002). Managing The Market Learning Process. Journal Of Business \& Industrial Marketing 17(4):240-252.

Dias, Alvaro, And Luis Filipe Lages. (2013). A Measure Of Market Sensing Capabilities. Europe Marketing Academy. University: Higher Institute Of Management And Administration.

Farida, Naili. (2016). Determinants Of Marketing Performance: Innovation, Market Capabilities And Marketing Performance. Jurnal Dinamika Manajemen 7(1):59-65. 
Fauzi, Devita Ekky, And Ibnu Widiyanto. (2015). Analisis Pengaruh Kapabilitas Penginderaan Pasar, Inovasi Produk, Dan Jejaring Pemasaran Terhadap Keunggulan Bersaing Pada Kinerja Pemasaran Ekspor (Studi Kasus Pada Eksportir Mebel Dari Kayu Di Kabupaten Jepara Jawa Tengah), Fakultas Ekonomika Dan Bisnis.

Ferdinand, A.T., And Maklon Filipus Killa. (2014). A Study On Backward Business Partner Networking Advantage And Pareto Distribution Network Accessibility As A Bridging Process For Marketing Performance: Indonesian Evidence. Eurasia Business And Economics Society.

Ferdinand, Augusty. (2000). Manajemen Pemasaran: Sebuah Pendekatan Stratejik. Research Paper Series 1:1-55.

Ferdinand, Augusty Tae, And Lili Karmela Fitriani. (2015a). Acculturative Iconic Product Attractiveness And Marketing Performance. Journal Of Global Strategic Management 2(9):15-15.

- (2015b). Acculturative Iconic Product Attractiveness And Marketing Performance.

Foley, Anthony, And John Fahy. (2004). Towards A Further Understanding Of The Development Of Market Orientation In The Firm: A Conceptual Framework Based On The Market-Sensing Capability. Journal Of Strategic Marketing 12(4):219-230.

Hinterhuber, Andreas. (2013). Can Competitive Advantage Be Predicted? Towards A Predictive Definition of Competitive Advantage In The Resource-Based View of The Firm. Management Decision 51(4):795-812.

Kara, Ali, John E Spillan, And Oscar W Deshields. (2005). The Effect Of A Market Orientation On Business Performance: A Study Of Small-Sized Service Retailers Using MARKOR Scale. Journal Of Small Business Management 43(2):105-118.

Kraus, Sascha, Rainer Harms, And Matthias Fink. (2009). Entrepreneurial Marketing: Moving Beyond Marketing In New Ventures. International Journal of Entrepreneurship And Innovation Management 11(1):19-34.

Lin, Jie-Heng, And Ming-Yeu Wang. (2015). Complementary Assets, Appropriability, And Patent Commercialization: Market Sensing Capability As A Moderator. Asia Pacific Management Review 20(3):141-147.

Lindblom, Arto Tapio, Et Al. (2008). Market-Sensing Capability And Business Performance Of Retail Entrepreneurs. Contemporary Management Research 4(3):17.

Lukiastuti, Fitri. (2013). Pengaruh Orientasi Wirausaha Dan Kapabilitas Jejaring Usaha Terhadap Peningkatan Kinerja Ukm Dengan Komitmen Perilaku Sebagai Variabel Interviening (Studi Empiris Pada Sentra UKM Batik Di Sragen, Jawa Tengah). Jurnal Organisasi Dan Manajemen 8(2):155-175.

Lumpkin, G. T., And Gregory G. Dess. (2001). Linking Two Dimensions Of Entrepreneurial Orientation To Firm Performance: The Moderating Role Of Environment And Industry Life Cycle. Journal of Business Venture 16:429-451.

Madsen, Einar Lier. (2007). The Significance Of Sustained Entrepreneurial Orientation On Performance of Firms - A Longitudinal Analysis. Entrepreneurship \& Regional Development 19(2):185-204.

Messaghem, K. (2003). Strategic Entrepreneurship And Managerial Activities In Smes. International Small Business Journal 21:2. 
Meutia. (2013). Improving Competitive Advantage And Business Performance Through The Development of Business Network, Adaptability of Business Environment And Innovation Creativity. Aceh International Journal of Social Sciences 2(1):10.

Mitrega, Maciej, Et Al. (2012). Networking Capability In Business Relationships-Concept And Scale Development. Industrial Marketing Management 41(5):739-751.

Mohebi, Mohammad Mehdi, And Sakineh Farzollahzade. (2014). Improving Competitive Advantage And Business Performance Of Smes By Creating Entrepreneurial Social Competence. MAGNT Research Report.

Morgan, Neil A, Douglas W Vorhies, And Charlotte H Mason. (2009). Market Orientation, Marketing Capabilities, And Firm Performance. Strategic Management Journal 30(8):909920.

Morris, Michael H, And Gordon W Paul. (2007). The Relationship Between Entrepreneurship And Marketing In Established Firms. Journal of Business Venturing 2(3):247-259.

Morris, Michael H., Schindehutte Minet, And Raymond W. Laforge. (2002). Entrepreneurial Marketing: A Construct For Integrating Emerging Entrepreneurship And Marketing Perspectives. Journal of Marketing Theory And Practice 10(4):1-19.

$\mathrm{Mu}$, Jifeng. (2014). Networking Capability, Network Structure, And New Product Development Performance. IEEE Transactions On Engineering Management 61(4):599-609.

$\mathrm{Mu}$, Jifeng, And Anthony Di Benedetto. (2012). Networking Capability And New Product Development. IEEE Transactions On Engineering Management 59(1):4-19.

Ong, Jeen Wei, Hishamuddin Bin Ismail, And Gerald Guan Gan Goh. (2010). The Competitive Advantage Of Small And Medium Enterprises (Smes): The Role Of Entrepreneurship And Luck. Journal of Small Business \& Entrepreneurship 23(3):373-391.

Parida, Vinit, Et Al. (2016). Network Partner Diversity, Network Capability, And Sales Growth In Small Firms. Journal of Business Research 69(6):2113-2117.

Parida, Vinit, Et Al. (2017). Network Capability, Innovativeness, And Performance: A Multidimensional Extension For Entrepreneurship. Entrepreneurship \& Regional Development 29(1-2):94-115.

Pratomo, Mohammad Rizky Teguh, And Ibnu Widiyanto. (2015). Analisis Pengaruh Kompetensi Wirausaha Dan Kemampuan Mengindera Pasar Terhadap Keunggulan Bersaing Untuk Meningkatkan Kinerja Pemasaran Studi Kasus Pada Usaha Mikro, Kecil Dan Menengah Kota Semarang, Fakultas Ekonomika Dan Bisnis.

Prayhoego, Callystha Adhelline. (2013). Analisa Pengaruh Total Quality Management Terhadap Keunggulan Bersaing Dan Kinerja Perusahaan. Business Accounting Review 1(2):236-245.

Rohmaniyah, Alfiatur, And Tatiek Nurhayati. (2017). Peningkatan Kreativitas Pemasaran Dan Kualitas Networking Berbasis Orientasi Pasar Terhadap Kinerja Pemasaran (Studi Kasus Pada CV. Mubarokfood Cipta Delicia Kudus). Jurnal Ekonomi \& Bisnis 18(2):149-163.

Saeko, A. N., Chuntarung \&Thoumrungroje, P. (2012). The Impact Of Integrated Marketing Strategy On Mareting Performance: An Empirical Evidence From Exporting Business In Thailand. International Journal of Business Strategy 12 (4).

Schilke, Oliver, And Anthony Goerzen. (2010). Alliance Management Capability: An Investigation of The Construct And Its Measurement. Journal of Management 36(5):1192-1219. 
Semrau, Thorsten, Tina Ambos, And Kraus Sascha. (2016). Entrepreneurial Orientation And SME Performance Across Societal Cultures: An International Study. Journal of Business Research 69(5):1928-1932.

Sigalas, Christos. (2015). Competitive Advantage: The Known Unknown Concept. Management Decision 53(9):2004-2016.

Sinkovics, Rudolf R, And Anthony S Roath. (2004). Strategic Orientation, Capabilities, And Performance In Manufacturer-3PL Relationships. Journal of Business Logistics 25(2):4364.

Slamet, Franky, And Denny Iskandar. (2017). Pengaruh Orientasi Pasar Dan Orientasi Kewirausahaan Terhadap Kinerja Usaha Pada Pemilik Ukm Sektor Manufaktur Garmien Di Tanah Abang, Jakarta Pusat. Ilmiah Manajemen Bisnis 16(1).

Stokes, David. (2000). Putting Entrepreneurship Into Marketing: The Processes of Entrepreneurial Marketing. Journal of Research In Marketing And Entrepreneurship 2(1):1-16.

Suryanita, Andriani. (2006). Analisis Pengaruh Orientasi Kewirausahaan Dan Kompetensi Pengetahuan Terhadap Kapabilitas Untuk Meningkatkan Kinerja Pemasaran (Studi Empirik Pada Industri Pakaian Jadi Di Kota Semarang), Program Pascasarjana Universitas Diponegoro.

Tang, Jintong, Et Al. (2007). The Impact Of Entrepreneurial Orientation And Ownership Type On Firm Performance In The Emerging Region Of China. Journal of Developmental Entrepreneurship 12(4):383-397.

Teece, David J. (2007). Explicating Dynamic Capabilities: The Nature And Microfoundations Of (Sustainable) Enterprise Performance. Strategic Management Journal 28(13):1319-1350.

Tregear, Angela. (2003). Market Orientation And The Craftsperson. European Journal Of Marketing 37(11/12):1621-1635.

Tseng, Shu-Mei, And Pei-Shan Lee. (2014). The Effect Of Knowledge Management Capability And Dynamic Capability On Organizational Performance. Journal of Enterprise Information Management 27(2):158-179.

Valeria, Nitya Pinasthika. (2013). Membangun Kinerja Bisnis Melalui Keunggulan Bersaing Pada Ukm Manufaktur (Studi Empirik Pada Industri Logam Di Kecamatan Caper, Kabupaten Klaten). Jurnal Bisnis Strategi 22(1):133-142.

Walter, Achim, Michael Auer, And Thomas Ritter. (2006). The Impact Of Network Capabilities And Entrepreneurial Orientation On University Spin-Off Performance. Journal Of Business Venturing 21(4):541-567.

Williams, D., \& Hare, L.,.(2012). Competitiveness Of Small Hotels In Jamaica: An Exploratory Analysis.: Ebscohost.

Zacca, Robert, Mumin Dayan, And Thomas Ahrens. (2015). Impact Of Network Capability On Small Business Performance. Management Decision 53(1):2-23. 